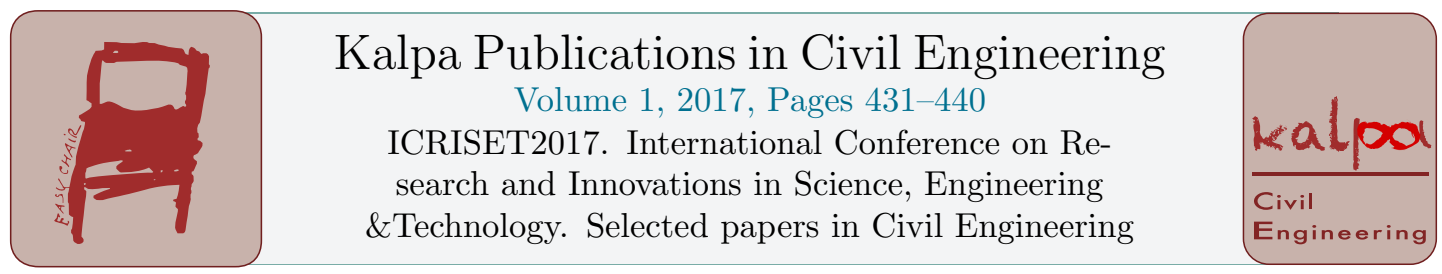

\title{
Optimum Utilization of GGBS in Fly Ash Based Geopolymer Concrete
}

\author{
Aanal Shah ${ }^{1 *}$ \\ ${ }^{1}$ Assistant Professor \\ Faculty of Technology, CEPT University, Ahmedabad, India \\ aanal.shah@cept.ac.in
}

\begin{abstract}
There have been increasing efforts in recent years to minimize the amount of cement used in concrete. Efforts at partial replacement have been successful and regulations have been promulgated to standardize and use such formulations. Research aimed at complete replacement of cement by activating industrial materials that are rich in silica and alumina with alkaline solutions is still on-going all over the world. The present study was aimed at complete elimination of cement through the development of a geopolymer concrete containing the mixture of fly ash and ground granulated blast furnace slag (GGBS), activated by sodium based alkaline activators. The effect of replacing up to $50 \%$ fly ash by GGBS was considered. The strength parameters were studied for a mixture of sodium silicate and sodium hydroxide solution having concentration $12 \mathrm{M}$. The samples were cured under ambient conditions as well as in an oven at $60^{\circ} \mathrm{C}$ for 24 hours. Compressive and split tensile strengths of the samples were measured on $3^{\text {rd }}, 7^{\text {th }}, 14^{\text {th }}, 28^{\text {th }}, 56^{\text {th }}$ and $90^{\text {th }}$ days of casting. The cubes were also tested for durability parameters by ponding in $\mathrm{NaCl}$ and $\mathrm{H}_{2} \mathrm{SO}_{4}$ solution for 28 and 90 days. It was observed that replacing fly ash with $30 \%$ of GGBS gave the best results.
\end{abstract}

\section{Introduction}

Portland cement concrete is an artificial stone, which is the mixture of Portland cement, water, sand and crushed stone aggregate. It is considered as an important building material in the world due to its versatility and possibility in offering architectural freedom (Glavind, M., 2009). With the increase in production of cement and development of infrastructure, problems related to climate change, sustainability, durability of structures and resource productivity have excelled and are now needed to be addressed (Mehta; P.K, 2003).

Extensive research is being carried out in the area of cement substitutes. Geopolymers are being considered as good replacements for cement. The complex process of geopolymerization has been explained by Davidovits (Davidovits, J., 1999). This mechanism includes four parallel stages, viz. 
dissolution of solid aluminosilicate materials, oligomerization of $\mathrm{Si}$ and/or $\mathrm{Si}-\mathrm{Al}$ in aqueous phase, polymerization of the oligomeric species, and bonding of undissolved solid particles in the polymer (Barbosa, V. F., MacKenzie, K. J., and Thaumaturgo, C, 2000) (Duxson, P.; Himenez, A. Fernandez; Provis, J. L.; Lukey, G. C.; Paloma, A.; Deventer, JSJ Van. , 2007) (Ridzuan, A.R.M., A.A.Khairulniza, and M.F. Arshad., 2014). Based on laboratory tests on fly ash based Geopolymer binder, Palomo, Grutzeck, and Blanco have shown that the curing temperature, curing time, and type of activator affected the compressive strength (Paloma, A., Grutzeck, M. W., \& Blanco, M. T., 1999). Van Jaarsveld, van Deventer, and Lukey confirmed the importance of curing at elevated temperature for fly ash based geopolymeric material (Van Jaarsveld, J. G., Van Deventer, J. S., \& Lukey, G. C.., 2002) . Hardjito, Wallah and Rangan showed that the use of solids/water ratios of $0.174,0.197$ and 0.220 resulted in $5-7 \%$ decrease of compressive strength for similar type of Geopolymer concrete. They also studied creep and shrinkage effects on fly ash based geopolymer concrete (D. Harjito; Rangan B.V; Curtin University of Technology, 2005).

The present paper describes the effective use of fly ash and GGBS as a replacement to cement in concrete along with the sodium based alkaline activators. The samples have been cured under ambient conditions as well as in an oven at $60^{\circ} \mathrm{C}$ for 24 hours.

\section{Experimental Program}

The physical and chemical properties of the source materials are as mentioned in table 1 . The dark grey coloured class $\mathrm{F}$ fly ash was procured from the silos of local thermal power station. GGBS was obtained from a manufacturing company in Goa. It was fine light brown colored powder.

\begin{tabular}{|l|l|l|}
\hline & Fly ash & GGBS \\
\hline $\mathrm{SiO}_{2}$ & $53.57 \%$ & $35.2 \%$ \\
\hline $\mathrm{Al}_{2} \mathrm{O}_{3}$ & $32.97 \%$ & $21.4 \%$ \\
\hline $\mathrm{Fe}_{2} \mathrm{O}_{3}$ & $5.51 \%$ & $1.8 \%$ \\
\hline $\mathrm{CaO}$ & $1.84 \%$ & $31.2 \%$ \\
\hline $\mathrm{MgO}$ & $0.92 \%$ & $8.4 \%$ \\
\hline $\mathrm{Na}_{2} \mathrm{O}$ & $0.37 \%$ & - \\
\hline $\mathrm{K}_{2} \mathrm{O}$ & $1.76 \%$ & - \\
\hline $\mathrm{TiO}_{2}$ & $2.1 \%$ & - \\
\hline $\mathrm{SO}_{3}$ & $0.46 \%$ & $0.15 \%$ \\
\hline $\mathrm{P}_{2} \mathrm{O}_{5}$ & $0.15 \%$ & - \\
\hline $\mathrm{Colour}^{2}$ & Light brown \\
\hline Fineness $\left(\mathrm{m}^{2} / \mathrm{kg}\right)$ & Grey & 400 \\
\hline Specific gravity & 325 & 2.9 \\
\hline
\end{tabular}

Table 1: Physical and Chemical properties of fly ash and GGBS

Coarse and fine aggregates were saturated-surface-dry as per Indian Standards. Coarse aggregates were obtained in crushed form; and were generally granitic. Coarse aggregates used were up to $20 \mathrm{~mm}$ size and locally available river sand was used as fine aggregates. Sodium based solutions were used as alkaline activators. Sodium hydroxide $(\mathrm{NaOH})$ solids were white coloured flakes having size (3-6 $\mathrm{mm}), 98 \%$ purity. Sodium silicate $\left(\mathrm{Na}_{2} \mathrm{SiO}_{3}\right)$ solution was in a thick gel form and was kept covered to 
avoid its drying and solidification. $\mathrm{NaOH}$ and $\mathrm{Na}_{2} \mathrm{SiO}_{3}$ were procured from local distributor (A. Shah, C. Shah, 2017). 12M concentrated $\mathrm{NaOH}$ solution was prepared by dissolving the required amount of $\mathrm{NaOH}$ flakes in water. It was prepared one day prior to casting and was mixed with $\mathrm{Na}_{2} \mathrm{SiO}_{3}$ solution a few minutes before the addition of the mixture to the source materials in concrete mixture (Lloyd, N. A., \& Rangan, B. V. , 2010). The ratio of alkaline liquid to source materials was kept 0.55 and that of $\mathrm{Na}_{2} \mathrm{SiO}_{3}$ to $\mathrm{NaOH}$ solution was 2. Water needed to make solutions and wash aggregates was normal tap water available in laboratory. Some amount of water was also added to source materials while mixing to increase the workability of the mix because super plasticizer was not used. The mixing, casting and curing of concrete was the same as that of conventional OPC concrete (A. Shah, C. Shah, 2017). Table 2 shows the mixture proportions adopted for this experimental study. The following methodology was adopted while giving designations to mixture proportions for further reference.

$\% \mathrm{~F} \% \mathrm{SXM}$ which is for:\% of fly ash (F) +\% of GGBS (S) + ' $\mathrm{X}$ ' Molarity of NaOH Solution

For example, $70 \mathrm{~F} 30 \mathrm{~S} 12 \mathrm{M}$ stands for $70 \%$ fly ash $+30 \%$ GGBS with $12 \mathrm{M}$ concentration of $\mathrm{NaOH}$.

\begin{tabular}{|l|l|l|l|l|l|l|}
\hline Designation & $90 \mathrm{~F} 10 \mathrm{~S} 12 \mathrm{M}$ & $80 \mathrm{~F} 20 \mathrm{~S} 12 \mathrm{M}$ & $70 \mathrm{~F} 30 \mathrm{~S} 12 \mathrm{M}$ & $60 \mathrm{~F} 40 \mathrm{~S} 12 \mathrm{M}$ & $50 \mathrm{~F} 50 \mathrm{~S} 12 \mathrm{M}$ & $\mathrm{Units}$ \\
\hline Fly ash & 382.5 & 340 & 297.5 & 255 & 212.5 & $\mathrm{~kg} / \mathrm{m}^{3}$ \\
\hline GGBS & 42.5 & 85 & 127.5 & 170 & 212.5 & $\mathrm{~kg} / \mathrm{m}^{3}$ \\
\hline $\begin{array}{l}\text { Coarse } \\
\text { aggregates }\end{array}$ & 1105 & 1105 & 1105 & 1105 & 1105 & $\mathrm{~kg} / \mathrm{m}^{3}$ \\
\hline Fine aggregates & 505 & 505 & 505 & 505 & 505 & $\mathrm{~kg} / \mathrm{m}^{3}$ \\
\hline Alkaline liquid & 233.75 & 233.75 & 233.75 & 233.75 & 233.75 & $\mathrm{~kg} / \mathrm{m}^{3}$ \\
\hline
\end{tabular}

Table 2: Mixture Proportion for Geopolymer concrete

\section{Results and Discussions : Compressive strength}

The mean compressive strengths of Geopolymer concrete cubes with the mixtures of fly ash and GGBS as source material cured under different temperatures are as per table 3 .

\begin{tabular}{|l|l|l|l|l|l|l|l|}
\hline Mix & $\begin{array}{l}\text { Curing } \\
\text { condition }\end{array}$ & 3 days & 7 days & 14 days & 28 days & 56 days & 90 days \\
\hline \multirow{2}{*}{ 90F10S12M } & Open air & 11.26 & 14.90 & 31.33 & 35.33 & 37.88 & 42.37 \\
\cline { 2 - 8 } & $60^{\circ} \mathrm{C}$ oven & 28.30 & 31.85 & 35.57 & 36.00 & 42.22 & 50.15 \\
\hline \multirow{2}{*}{$80 \mathrm{~F} 20 \mathrm{~S} 12 \mathrm{M}$} & Open air & 17.19 & 24.56 & 39.01 & 46.67 & 48.43 & 48.40 \\
\cline { 2 - 8 } & $60^{\circ} \mathrm{C}$ oven & 33.50 & 37.76 & 48.09 & 52.44 & 55.26 & 55.55 \\
\hline \multirow{2}{*}{ 70F30S12M } & Open air & 27.70 & 40.01 & 48.24 & 52.31 & 54.41 & 54.12 \\
\cline { 2 - 8 } & $60^{\circ} \mathrm{C}$ oven & 38.99 & 45.63 & 50.40 & 52.80 & 55.99 & 57.42 \\
\hline \multirow{2}{*}{$60 \mathrm{~F} 40 \mathrm{~S} 12 \mathrm{M}$} & Open air & 20.87 & 34.37 & 41.45 & 44.34 & 44.83 & 45.02 \\
\cline { 2 - 8 } & $60^{\circ} \mathrm{C}$ oven & 34.21 & 44.74 & 44.24 & 46.67 & 49.78 & 52.19 \\
\hline \multirow{2}{*}{ 50F50S12M } & Open air & 22.50 & 36.15 & 43.10 & 43.33 & 44.09 & 44.39 \\
\cline { 2 - 8 } & $60^{\circ} \mathrm{C}$ oven & 37.48 & 43.11 & 47.66 & 48.43 & 51.42 & 51.54 \\
\hline
\end{tabular}

Table 3: Mean Compressive strength of Geopolymer concrete in $\mathrm{N} / \mathrm{mm}^{2}$ 


\subsection{Curing at ambient conditions}

The following figure 1 show compressive strength of the specimens cured under ambient condition.

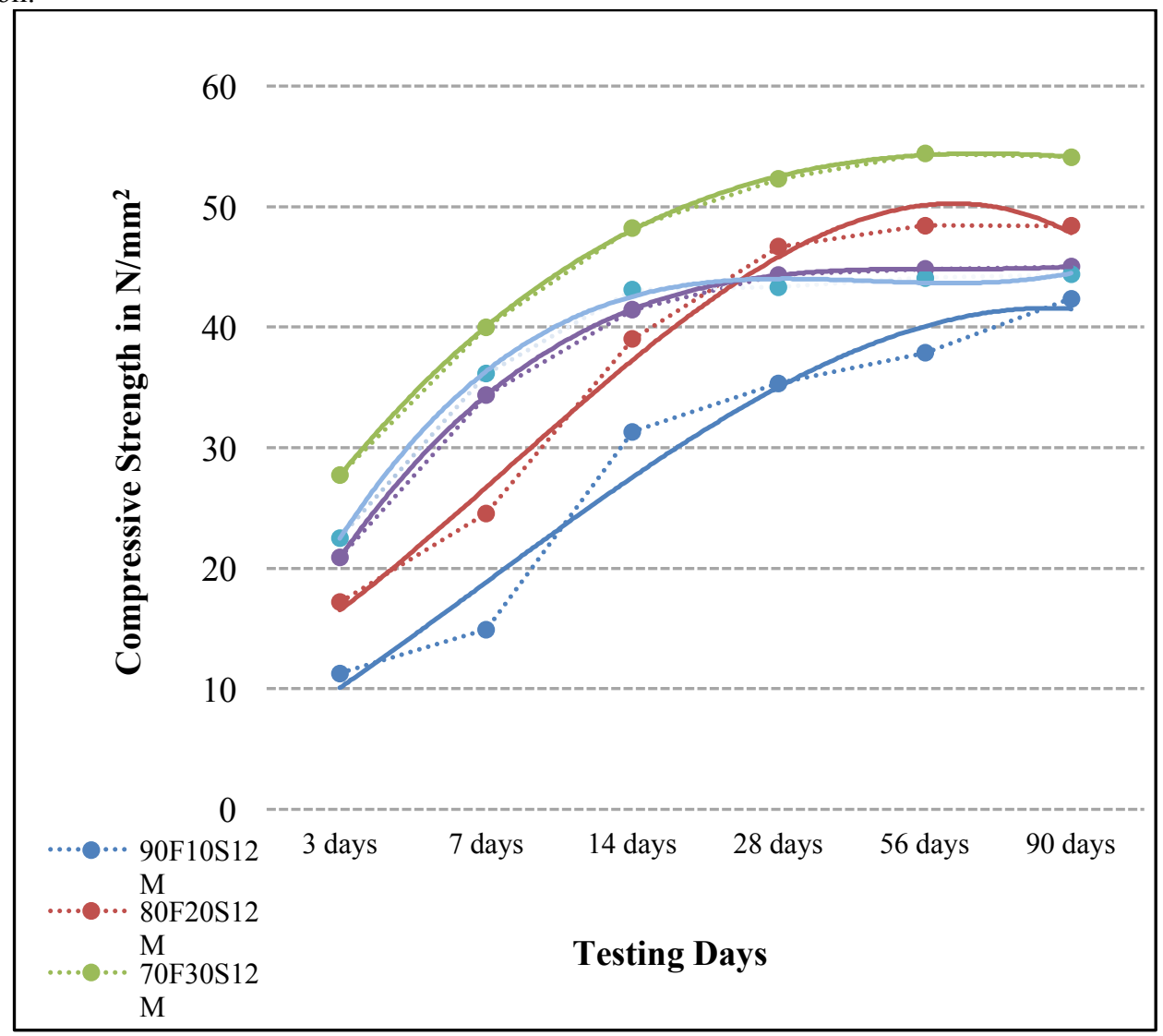

Figure 1: Mean compressive strength $\left(\mathrm{N} / \mathrm{mm}^{2}\right)$ of Geopolymer concrete cured at ambient temperature

Overall comparison of the results shows that the mixture of $70 \%$ of fly ash and $30 \%$ GGBS gives higher values as compared with other mixtures. Compressive strength gain for $10 \%$ and $20 \%$ replacement of fly ash results in lower strength in early days, but then the mechanism of strength gain is consistently at higher rate and is at par with other mixtures. Compressive strength gain for mixtures with $40 \%$ and $50 \%$ replacement of fly ash is higher during the initial days, but the strength development rate is less as compared to other mixtures. The mixtures with $10 \%, 20 \%$ and $30 \%$ of replacement have almost $75-85 \%$ of $90^{\text {th }}$ day strength by $14^{\text {th }}$ day. For other mixtures, if is $95 \%$ of $90^{\text {th }}$ day strength. Almost $97 \%$ of strength of 90 days is achieved within 28 days of casting for all mixtures except for the mixture with $10 \%$ GGBS.

\subsection{Oven curing at $60^{\circ} \mathrm{C}$}

The following figure 2 shows compressive strength of the specimens cured in oven at $60^{\circ} \mathrm{C}$ for 24 hours. 


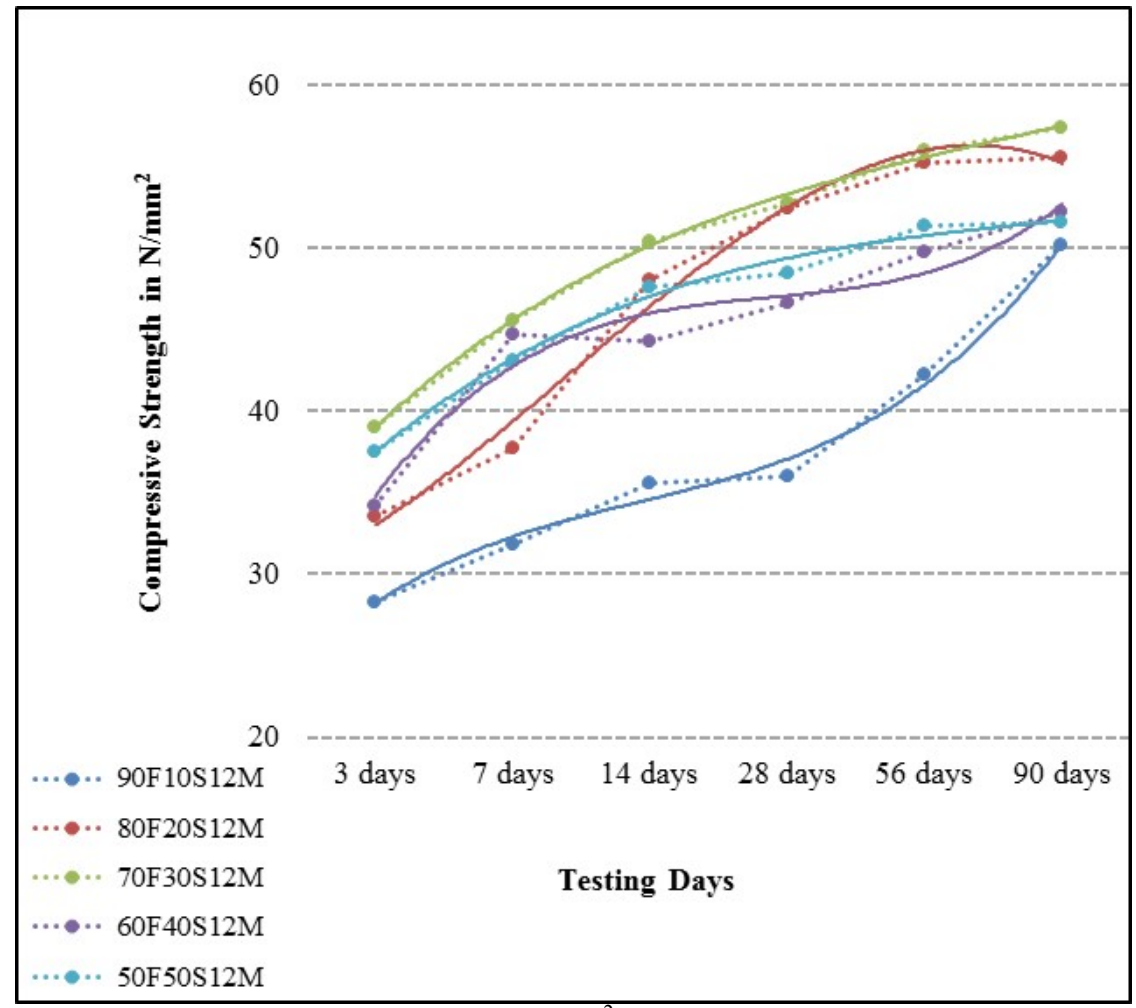

Figure 2: Mean compressive strength $\left(\mathrm{N} / \mathrm{mm}^{2}\right)$ of Geopolymer concrete cured at $60^{\circ} \mathrm{C}$

Overall comparison of the results shows that the mixture of $70 \%$ of fly ash and $30 \%$ GGBS has higher values than other mixtures. Compressive strength gains for $10 \%$ and $20 \%$ replacement of fly ash are lower during the early days, but the mechanism of strength gain is consistently at higher rate and is at par with other mixtures. Compressive strength gain for mixtures with $40 \%$ and $50 \%$ replacement of fly ash is higher during the initial days, but the strength development rate is less than for other mixtures. Almost $70 \%$ of strength of 90 days is achieved within 14 days and 28 days of casting for mixtures having replacement of $10 \%$ of fly ash with GGBS. About $85-90 \%$ of strength is achieved for all other mixtures. About $60-70 \%$ of 90 days strength is observed during the first 14 days for mixtures having $10-20 \%$ replacement of fly ash. For other mixtures, this value is $85-95 \%$. 

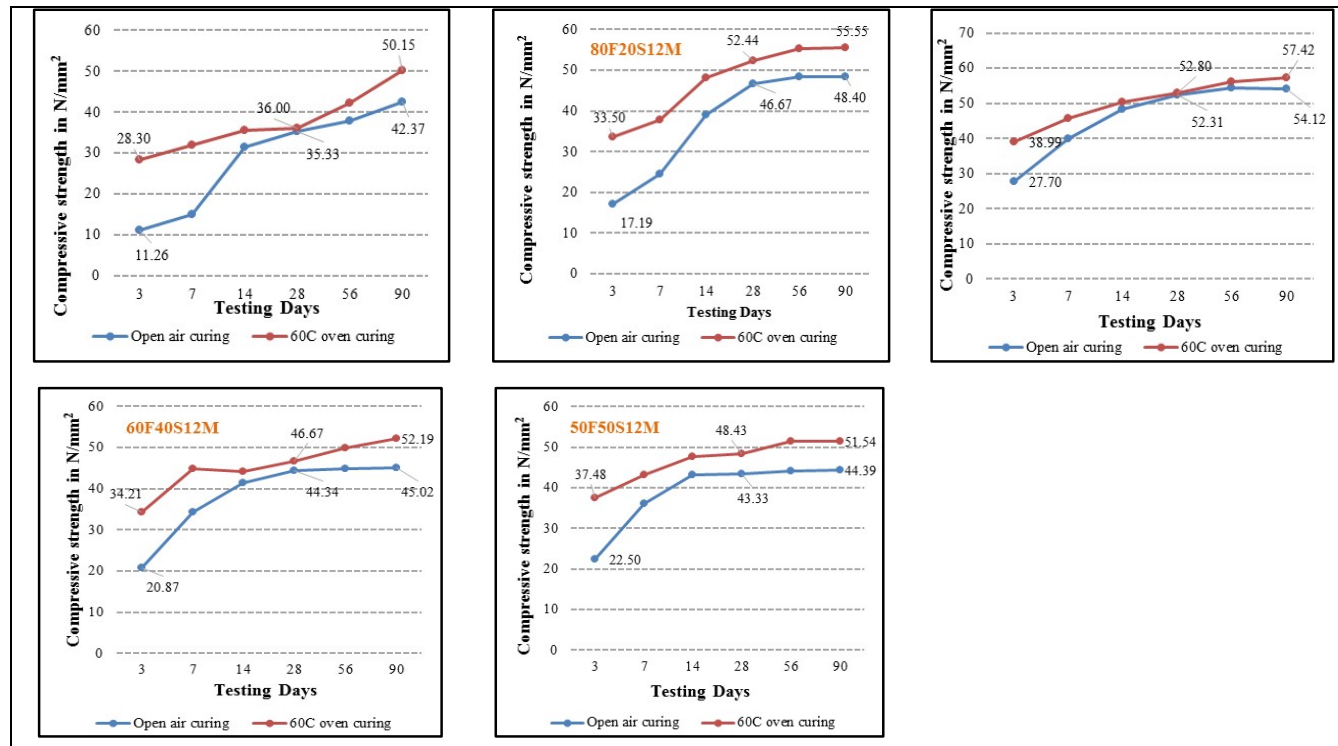

$\rightarrow$ Open air curing $\rightarrow-60 \mathrm{C}$ oven curing

Figure 3: Comparison of Compressive strength under ambient and oven conditions

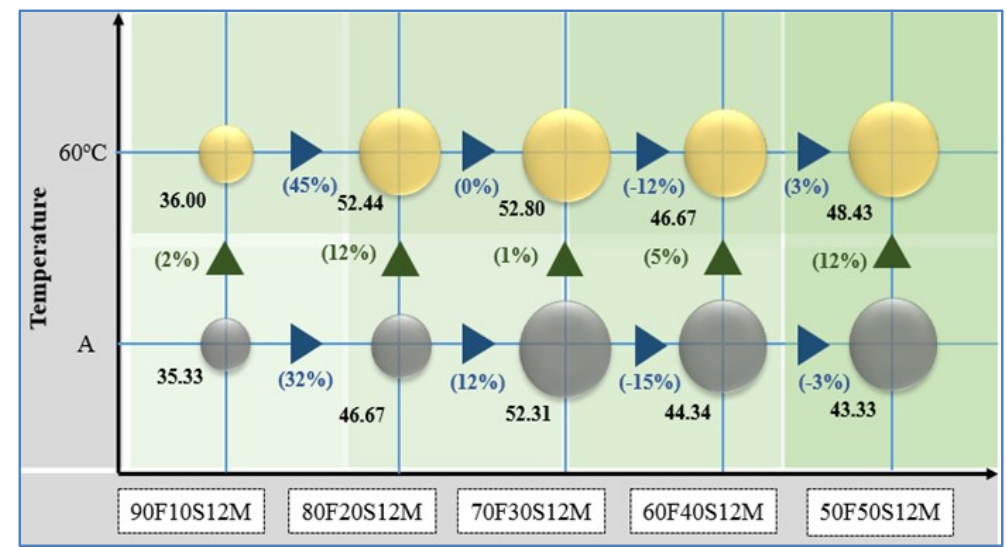

Figure 4: Effect of temperature and fly ash replacement on $28^{\text {th }}$ day compressive strength

All mixtures have similar strength gaining behaviour. Initial difference in compressive strength ranges from $150 \%$ to $40 \%$ for 3 days strength, which tends to converge during $28^{\text {th }}$ day. The difference during $28^{\text {th }}$ day is not more than $12 \%$. However, if the values studied for $90^{\text {th }}$ day, the difference due to oven curing still ranges from 5\% to 20\%. As GGBS content increases, the initial strength gain also increases. Along with that it is also observed that the difference between the compressive strength with ambient and oven curing also decreases. In terms of strength gain mechanism, the mixture with $70 \%$ fly ash and $30 \%$ GGBS with $12 \mathrm{M} \mathrm{NaOH}$ solution has similar strength after 28 days, irrespective of curing condition. At the age of 90 days, overall difference in compressive strength is about $10 \%$ for all mixtures having the same curing condition. Compressive strength for each mixture does not differ by more than $15 \%$ due to changes in curing condition. 


\section{Results and Discussions : Split tensile strength}

Mean split tensile strength values of geopolymer concrete with mixture of fly ash and GGBS as source material are as under.

\begin{tabular}{|l|l|l|}
\hline Mix & Curing condition & Split tensile strength $\left(\mathrm{N} / \mathrm{mm}^{2}\right)$ \\
\hline \multirow{2}{*}{$90 \mathrm{~F} 10 \mathrm{~S} 12 \mathrm{M}$} & Open air & 2.35 \\
\cline { 2 - 3 } & $60^{\circ} \mathrm{C}$ oven & 2.69 \\
\hline \multirow{2}{*}{$80 \mathrm{~F} 20 \mathrm{~S} 12 \mathrm{M}$} & Open air & 2.89 \\
\cline { 2 - 3 } & $60^{\circ} \mathrm{C}$ oven & 3.21 \\
\hline \multirow{2}{*}{$70 \mathrm{~F} 30 \mathrm{~S} 12 \mathrm{M}$} & Open air & 3.27 \\
\cline { 2 - 3 } & $60^{\circ} \mathrm{C}$ oven & 3.56 \\
\hline \multirow{2}{*}{$60 \mathrm{~F} 40 \mathrm{~S} 12 \mathrm{M}$} & Open air & 2.98 \\
\cline { 2 - 3 } & $60^{\circ} \mathrm{C}$ oven & 3.33 \\
\hline \multirow{2}{*}{$50 \mathrm{~F} 50 \mathrm{~S} 12 \mathrm{M}$} & Open air & 3.16 \\
\cline { 2 - 3 } & $60^{\circ} \mathrm{C}$ oven & 3.25 \\
\hline
\end{tabular}

Table 4: Mean Split tensile strength of Geopolymer concrete in $\mathrm{N} / \mathrm{mm}^{2}$

The geopolymer concrete with mixture of fly ash and GGBS as a source material has split tensile of about $6-7 \%$ of the corresponding compressive strength. These tests are performed with same molarity and oven curing is done at $60^{\circ} \mathrm{C}$. Also, for oven based samples it is about $5-15 \%$ more than those cured under open air. These values may differ with molarity and curing temperature. These values may also differ with respect to fineness and purity of source materials and activators respectively. Following figure 5 shows the relationship between compressive strength and split tensile strength of this type of concrete.

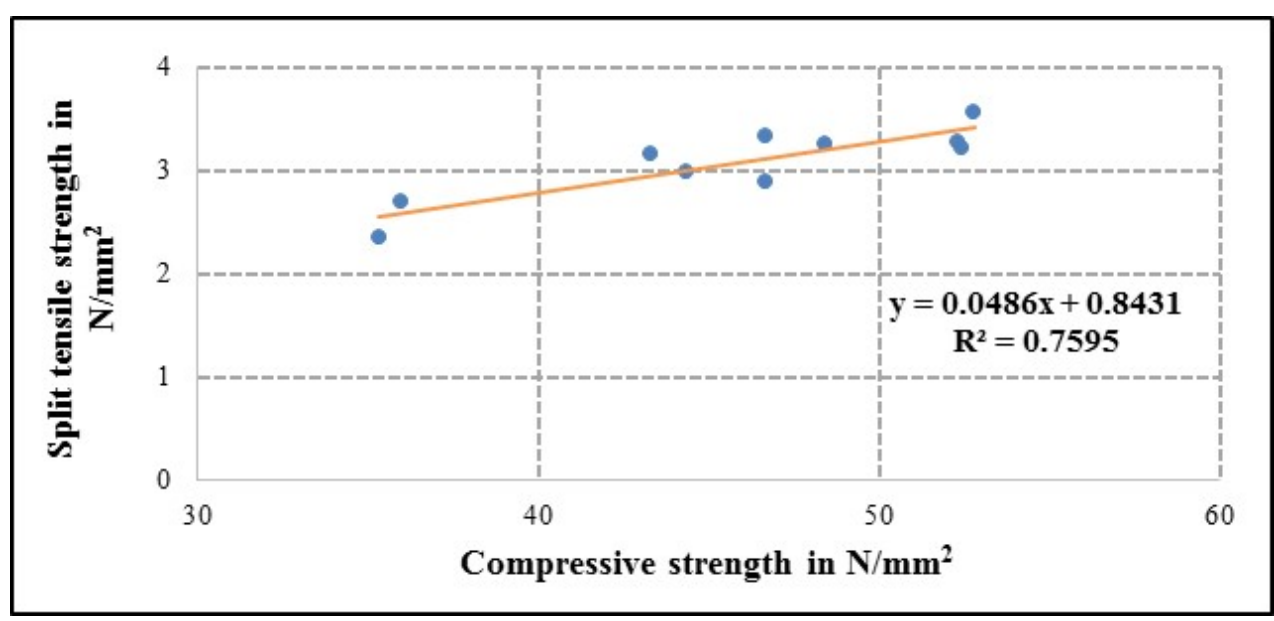

Figure 5: Relationship of compressive strength and split tensile strength of Geopolymer concrete 


\section{Results and discussions: effect of ponding the cubes in $\mathrm{NaCl}$ and $\mathrm{H}_{2} \mathrm{SO}_{4}$ solutions}

The oven-cured cubes submerged in $3.5 \% \mathrm{NaCl}$ solution for 28 days and 90 days with alternate wetting and drying cycles. About $2 \%$ loss in strength observed when ponded for 28 days. This difference increases to about $5-7 \%$ after that for 90 days. Average compressive strength for each mixture is as under in figure 6 .

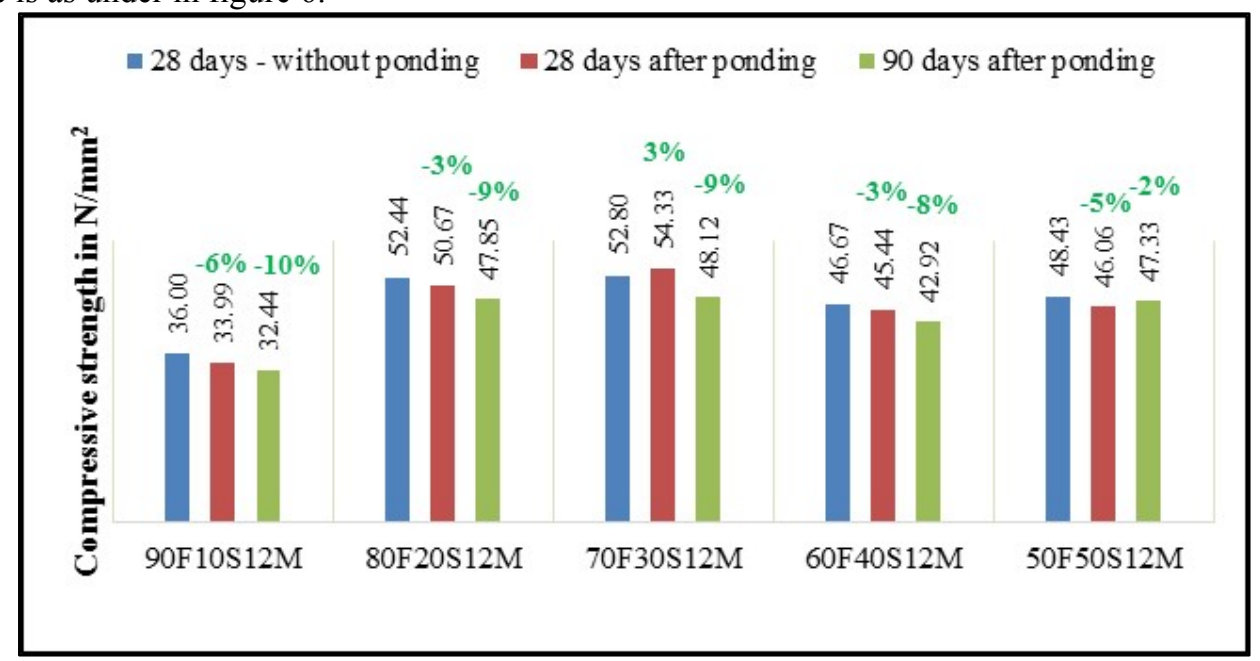

Figure 6: Effect of ponding in $\mathrm{NaCl}$ solution

The cubes submerged in $5 \% \mathrm{H}_{2} \mathrm{SO}_{4}$ solution for 28 days and 90 days with alternate wetting and drying. Average compressive strength for each mixture is as under in figure 7. Overall decrease in compressive strength is about $5 \%$ to $15 \%$ after ponding the cubes for 28 days. About $20 \%$ decrease in strength is observed when cubes are kept in the solution for 90 days.

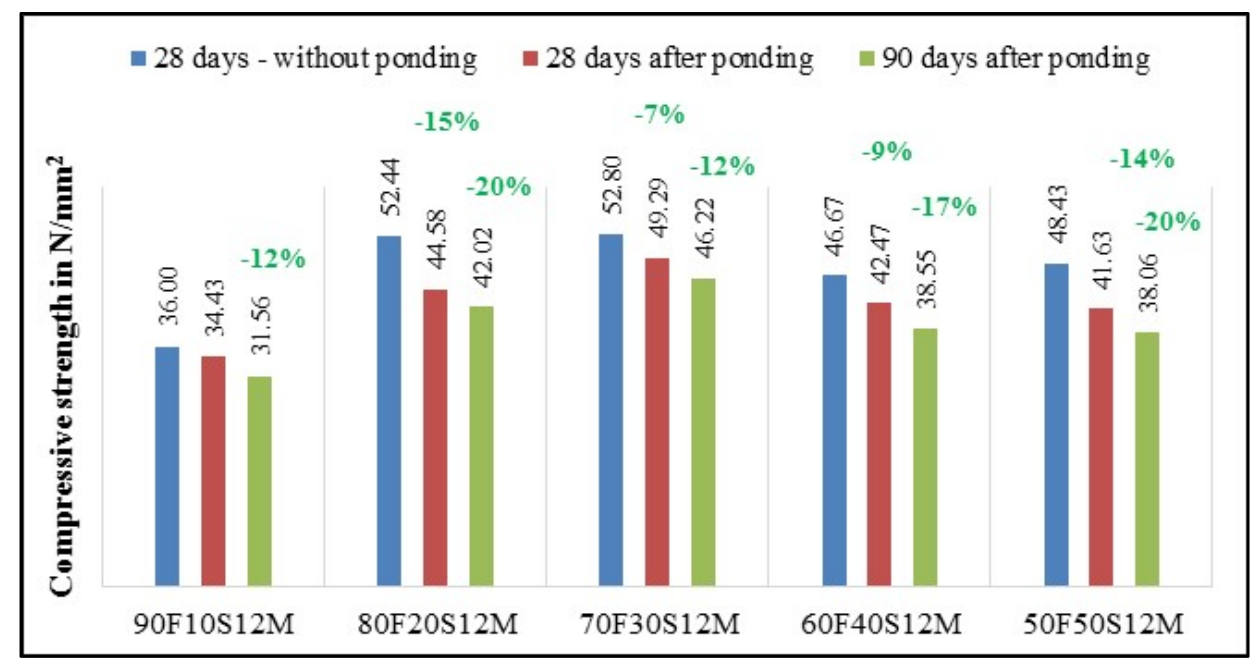

Figure 7: Effect of ponding in $\mathrm{H}_{2} \mathrm{SO}_{4}$ solution 


\section{Conclusion}

Compressive strength gain is a complex process due to mixing of two materials having different chemical properties. The strength development of mixture having $10 \%$ and $20 \%$ of replacement of fly ash is slow as compared to that of $30 \%-50 \%$ of replacement. This material undergoes the processes of polymerization and hydration, depending on its mixture proportions. Adding GGBS to the fly ash for making Geopolymer concrete results in higher early strength and cubes demoulded by next day. The rate of strength development is faster during early days for mixtures having $30-50 \%$ replacement of fly ash through GGBS, but after 28 days, the strength gain is at lower rate. However, for the mixture proportion having $10-20 \%$ of replacement of fly ash with GGBS, the rate of strength development is slow and steady and continues after 28 days. Mixture of 70\% fly ash and 30\% GGBS shows highest values of compressive strength. The loss in compressive strength is about $2-5 \%$ and $5-15 \%$ after ponding the cubes in $\mathrm{NaCl}$ and $\mathrm{H}_{2} \mathrm{SO}_{4}$ solutions respectively for 90 days.

The benefits of strength, durability and costs make geopolymers worthwhile replacements to cement and it is in the best interest of the construction industry to be aware of and start using this material. Immediate adoption is impeded by absence of codal regulations and specifications, and it is perhaps an uphill task to replace a material that has been extensively used for more than 150 years. Although the application of geopolymer in practical construction has already begun in some parts of world, it will take time to understand the material and its technology and make it accepted worldwide (Paloma, A., Grutzeck, M. W., \& Blanco, M. T. , 1999) (Palomo,A,; Krivenko, P.; Garcia-Lodeiro, I.; Kavalerova, E.; Maltseva, O,; Fernandez-Jimenez, A, 2014)

\section{References}

A. Shah, C. Shah. (2017). Effect of chemical composition of different source materials on 28th day compressive strength of geopolymer concrete cured under ambient conditions.

Barbosa, V. F., MacKenzie, K. J., and Thaumaturgo, C. (2000). Synthesis and Characterization of Materials Based on Inorganic Polymers of Alumina and Silica : Sodium Polysialate Polymers. International Journal of Inorganic Materials, 309-317.

D. Harjito; Rangan B.V; Curtin University of Technology. (2005). Development and properties of low-calcium fly ash-based Geopolymer concrete-Research report GC1. Perth: Curtin University of Technology.

Davidovits, J. (1999). Chemistry of Geopolymeric Systems, Terminology. Geopolymer International Conference, (pp. 9-40). France.

Duxson, P.; Himenez, A. Fernandez; Provis, J. L.; Lukey, G. C.; Paloma, A.; Deventer, JSJ Van. . (2007). Geopolymer Technology : The Current State of the Art. Journal of material science,, 2917-2933.

Glavind, M. (2009). Sustainability of cement, concrete and cement replacement materials in construction. Sustainability of construction materials.

Lloyd, N. A., \& Rangan, B. V. . (2010). Geopolymer Concrete with Fly Ash . Second International Conference on Sustainable Construction Materials and Technology, (pp. 1493-1504). Ancona, Italy.

Mehta; P.K. (2003). High-Performance, High-Volume Fly ash Concrete for Sustainable Development,. International Workshop on Sustainable Development and Concrete Technology, (pp. 3-14). Berkeley, USA. 
Paloma, A., Grutzeck, M. W., \& Blanco, M. T. . (1999). Alkali-Activated Fly Ashses : A Cement for the Future . Cement and Concrete Research, 1323-1329.

Paloma, A., Grutzeck, M. W., \& Blanco, M. T. . (1999). Alkali-Activated Fly Ashses : A Cement for the Future . Cement and Concrete Research, 1323-1329.

Palomo,A,; Krivenko, P.; Garcia-Lodeiro, I.; Kavalerova, E.; Maltseva, O,; Fernandez-Jimenez, A. (2014). A review on alkaline activation: new analytical perspectives. Materiales de construccion, 1-24.

Ridzuan, A.R.M., A.A.Khairulniza, and M.F. Arshad. (2014). Effect of Sodium Silicate types on the High Calcium Geopolymer Concrete. Material Science Forum.

Van Jaarsveld, J. G., Van Deventer, J. S., \& Lukey, G. C.. (2002). The Effect of Composition and Temperature on the Properties of Fly ASh and Kaolinite-Based Geopolymers. Chemical Engineering Journal, 63-73. 